\title{
Hepatitis Screening and Treatment Campaign in Malaysia- Validation of Low-cost Point of Care Screening Tests and Nucleic Acid Tests for Hepatitis B and C
}

\footnotetext{
${ }^{1}$ Muhammad Radzi AH, ${ }^{2}$ Soek S Tan, ${ }^{3}$ Rosmawati Mohamed, ${ }^{4}$ Fauziah Jaya, ${ }^{5}$ Senamjit K, ${ }^{6}$ Azlida C Aun, ${ }^{7}$ Ghazali A Kutty, ${ }^{8} \mathrm{Hin} \mathrm{S}$ Wong, ${ }^{9}$ Rafidah Abdullah, ${ }^{10}$ Mohd R Seman, ${ }^{11}$ Mamun Al Mahtab, ${ }^{12}$ Zaki Morad, ${ }^{13}$ Teck-Onn Lim

${ }^{1}$ Hospital Sultanah Bahiyah, Alor Setar, Malaysia, ${ }^{2}$ Hospital Selayang, Selangor, Malaysia, ${ }^{3}$ University Malaya Medical Centre, Kuala Lumpur, Malaysia, ${ }^{4}$ Gastroenterology and Hepatology, Hospital Raja Permaisuri Bainun, Ipoh Perak, Malaysia, ${ }^{5}$ Hospital, Raja Permaisuri Bainun Ipoh, Perak, Malaysia, ${ }^{6}$ Gastroenterology, Hospital Tengku, Ampuan Afzan, Kuantan, Pahang, Malaysia, ${ }^{7}$ Nephrologist, Hospital Kuala Lumpur, Malaysia, ${ }^{8} \mathrm{Hospital}$ Selayang, Selangor, Malaysia, ${ }^{9} \mathrm{Hospital}$ Temerloh, Pahang, Malaysia, ${ }^{10} \mathrm{Hospital}$ Tengku, Ampuan Afzan, Kuantan, Pahang, Malaysia, ${ }^{11}$ Department of Hepatology, Bangabandhu Sheikh Mujib Medical University, Dhaka, Bangladesh, ${ }^{12}$ National Kidney Foundation, Kuala Lumpur, Malaysia, ${ }^{13}$ Hepatitis Free Pahang Society, Pahang Malaysia
}

\begin{abstract}
SUMMARY
Background: Two major challenges in implementing budget-constrained Hepatitis screening and treatment campaign in Malaysia are the availability of low-cost point of care tests (POCT) and nucleic acid tests (NAT) for hepatitis $C$ virus ribonucleic acid (HCV RNA) and hepatitis $B$ virus dioxyribo nucleic acid (HBV DNA). We evaluated the performance of these tests in this study.

Methods: We conducted a cross-sectional study to evaluate the diagnostic performance of four POCT brands at 12 sites in Malaysia. We assessed the sensitivity and specificity of the POCTs for the detection of $\mathrm{HBsAg}$ and anti-HCV in a finger-stick capillary or venepuncture whole-blood samples compared with test results from lab-based enzyme immunoassay (EIA) or chemi-luminescence immunoassay (CLIA) assay as the reference standard. We also conducted a cross-sectional study on 30 to 139 serum specimen panel to evaluate the diagnostic performance of a low-cost in-house Applied Biosystem®TaqMan real-time polymerase chain reaction (PCR) assay (ABS) for the detection of HCV RNA and HBV DNA, compare with Roche Cobas ${ }^{\circ}$ Ampliprep/TaqMan assay (COBAS).
\end{abstract}

Results: Between March and December 2017, we enroll 295 participants for the evaluation of POCT for HBsAg and another 307 participants for POCT anti-HCV evaluation. Three of the four POCT brands dropped out of evaluation early on account of sub-optimal sensitivity. The sensitivity of the remaining POCT for HBsAg was $95.2 \%$ and specificity $100 \%$, while the POCT for anti-HCV has a sensitivity of $98.1 \%$ and specificity $100 \%$.

Hepatitis B virus dioxyribo nucleic acid and HCV RNA concentrations detected by the ABS were systematically higher than those measured by COBAS (mean bias +0.10 and $+0.17 \log 10 \mathrm{IU} / \mathrm{mL}$ respectively). The $95 \%$ limits of agreement between the two assays are -1.28 to $1.47 \log 10 \mathrm{IU} / \mathrm{mL}$ for HBV DNA and -0.41 to $0.75 \mathrm{log} 10 \mathrm{IU} / \mathrm{mL}$ for HCV RNA.

Conclusion: We found adequate evidence for the diagnostic validity of a low-cost POCT for anti-HCV and HBsAg, as well as for an in-house nucleic acid tests (NAT), to provide support for their broader use in our Hepatitis screening and treatment campaign.

Keywords: Access to treatment, Diagnostic test, Health services, Hepatitis B, Hepatitis B virus dioxyribo nucleic acid, Hepatitis C, Hepatitis C virus ribonucleic acid, Nucleic Acid Tests, Point of Care tests, Screening, Validation.

Abbreviations: ABS: Applied Biosystem®TaqMan real-time PCR assay, Cl: Confidence interval, CLD: Chronic liver disease, CLIA: Chemi-luminescence immunoassay, COBAS: Roche Cobas ${ }^{\circledR}$ Ampliprep/ TaqMan assay, DAA: Direct Acting Anti-Viral drugs, EIA: Enzyme immunoassay, HBV: Hepatitis B virus, HCV: Hepatitis C virus, HFPM: Hepatitis Free Pahang Malaysia, LOA: Limits of agreement, LOD: Limit of detection, MOH: Ministry of Health, Malaysia, NAT: Nucleic Acid Tests, POCT: Point of Care Tests, SD: Standard deviation, WHO: World Health Organization

How to cite this article: Radzi AHM, Tan SS, Mohamed R, Jaya F, Senamjit K, Aun AC, Kutty GA, Wong HS, Abdullah R, Seman MR, Mahtab MA, Morad Z, Lim TO. Hepatitis Screening and Treatment Campaign in Malaysia-Validation of Low-cost Point of Care Screening Tests and Nucleic Acid
Tests for Hepatitis B and C. Euroasian J Hepatogastroenterol, 2018;8(2):101-107.

Source of support: The National Kidney Foundation Malaysia funds this study

Conflict of interest: None

Address reprint request to: Teck-Onn Lim, Hepatitis Free Pahang Malaysia, Petaling Jaya, Selangor, Malaysia, Phone:+60378313752, e-mail: limteckonn@gmail.com 


\section{INTRODUCTION}

According to the Global Burden of Disease Study 2010, chronic liver disease (CLD) ranks ninth among the top 10 major disease burden in Malaysia. ${ }^{1}$ Each year in Malaysia, about 1500 people died of CLD. ${ }^{2}$ Globocan $^{3}$ estimated another 1750 people died of liver cancer, the fourth most common cause of cancer deaths in Malaysia after lung, breast, and colorectal cancers. In South-East Asia, it is estimated that $27 \%$ and $23 \%$ of deaths from CLD are attributable to Chronic Hepatitis B (HBV) and Hepatitis $\mathrm{C}$ virus $(\mathrm{HCV})$ infection respectively, while alcohol accounts for another 19\% of CLD deaths. ${ }^{2}$ The estimated prevalent count of HBV carrier in Malaysia is 250,000 adults (prevalence rate $1.5 \%$; children are relatively unaffected because of vaccination which was introduced since 1989), and another 400,000 people have been infected by $\mathrm{HCV}$ (prevalence rate $2 \%$ ). Hence Chronic $\mathrm{HBC}$ and $\mathrm{HCV}$ are likely major causes of CLD and liver cancer in Malaysia, though admittedly in the absence of population-based epidemiologic studies, these estimates are derived from studies on blood donors, patients on dialysis or from single tertiary institutions ${ }^{4-17}$ or were modeled estimates. ${ }^{18-20}$

Recent therapeutic advances have rendered both chronic HBV and HCV treatable. HCV, in particular, is curable with modern direct acting anti-viral (DAA) therapies. ${ }^{21}$ In spite of being an upper middle-income country, screening services for HBV and HCV in Malaysia remain under-developed, and access to modern antiviral therapies is even more limited. ${ }^{22}$ There is a need for concerted public actions to address hepatitis as a significant public health concern. However, there is little progress on the public policy front to allocate significant healthcare resources to support hepatitis screening and treatment services in Malaysia. In response, a nongovernmental organization, the Hepatitis Free Pahang Malaysia (HFPM) ${ }^{23}$ was recently established to mobilize local community organizations, health care providersand individual concerned citizens to address Hepatitis health; specifically to raise awareness about $\mathrm{HBV}$ and $\mathrm{HCV}$, to provide low cost public screening services and improve access to costly treatments for chronic HCV and HBV in Malaysia. The HFPM has launched its hepatitis campaign ona pilot scale in Pahang since August 2017 and more recently in other parts of Malaysia. The campaign is entirely funded by charity and by HFPM partners comprising local social or faith-based organizations and local healthcare providers as part of their community outreach efforts.

For a low budget charity funded campaign to effectively and ethicallyconduct public screeningand treatment for $\mathrm{HBV}$ and $\mathrm{HCV}$ on a large scale, we must overcome five major challenges:

Effective social marketing to raise public awareness about HBV and HCV through a variety of channels and media, and to engage the public and inviting them to come forward for screening at our health fairs or opportunistically at participating primary care and pharmacy outlets. This is currently conducted by HFPM together with our partners. To date in our pilot campaign, we have screened 1636 individuals, and 27 people were confirmed to be positive (19 HBsAg+ and eight anti-HCV +).

Public screening entails testing huge number of people in the community. It must necessarily employ robust low-cost POCT which is simple to perform (minimal training and no equipment required) and which provides a result on the spot. ${ }^{24}$ These tests are available but costly. Based on our budgetary consideration, the cost of POCT to sustain our campaign should be below USD 0.50 per person screened.

Subjects who are screened positive from the abovementioned public campaign will require confirmatory lab-based serological tests as well as nucleic acid tests (NAT) for HCV RNA and HBV DNAtoguide treatment decision. These tests are available but very costly. Based on our budgetary consideration, the cost of NAT should be below USD 20 per test.

Subjects who are confirmed positive with detectable HCV RNA or high HBV DNA levels, among other considerations, will need anti-viral treatment. These medicines are very costly. We follow Australian lead ${ }^{25}$ in using low cost personally imported generic medicines ${ }^{26}$ from India and Bangladesh. However, given the uncertain safety and efficacy of these imported medicines, we have established a patient registry to track the outcomes of treated patients including to determine the sustained virological response (SVR) rates achieved. The registry also serves as an active surveillance system to monitor the safety of these drugs and to collect sample drugs from the diverse supply sources to measure their composition.

In scaling up the Hepatitis campaign, a large number of patients with chronic HBV and HCV will be identified, and they will require medical care. In Malaysia, these patients have hitherto been managed by specialist Gastroenterologists, the supply of whom is minimal. For example, in Pahang with a population of 1.6 million and where the pilot campaign is ongoing, there is only one Gastroenterologist in the public hospital and 2 in private, all are located far away in the capital city Kuantan. In line with current WHO guidelines, ${ }^{27,28}$ we mobilize the local primary care workforce where the campaign is conducted to deliver the medical care for the patients with 
uncomplicated chronic HBV or HCV who are identified through our campaign.

\section{In this Study, we aimed to Evaluate}

The diagnostic performance of POCTs donated by or purchased from a variety of manufacturers on both finger-stick capillary as well as venepuncture wholeblood samples. The performance results will guide the selection of low-cost POCT for subsequent large-scale use in our public screening campaign.

The diagnostic performance of low-cost HCV RNA and HBV DNA tests for broader use in the treatment campaign.

\section{METHODS}

\section{Validation of POCT for Detecting Anti-HCV and HBsAg}

We conducted a cross-sectional study to evaluate the diagnostic performance of POC tests acquired from 4 manufacturers between March and December 2017. The Ministry of Health's (MOH) Medical and Research Ethics Committee approved the study, and all patients gave written informed consent.

\section{Study Patients}

Participants for this study were enrolled from 12 sites in Malaysia. These sites comprise five Medical/Gastroenterology outpatient clinics and 7 hemodialyses (HD) centers.

To estimate the test sensitivity, we enroll patients aged 18 or older who were positive for anti-HCV or HBsAg. Patients' HBV or HCV status were verified by the presence of positive results from lab tests using enzyme immunoassay (EIA) and besid es for anti-HCV, chemiluminescence immunoassay (CLIA). Exclusion criteria were a history of HBV vaccination or undetectable HCV RNA.

To estimate the test specificity, we enrolledsubjects from the public who had come forward to attend HBV and HCV screening and who were tested negative for anti-HCV or HBsAgusing enzyme immunoassay (EIA).

\section{POCT Tests under Evaluation and Procedures}

We identified four manufacturers who agreed to supply POCTs at a low cost to meet our budgetary constraint. POCTs from these sources use the immune-chromatographic method in a lateral flow device to detect anti-HCV antibodies or HBsAg in whole blood collected by finger stick, or serum, plasma or whole-blood collected by venepuncture. In these devices, human plasma-derived antihepatitis B surface antibodies or synthetic recombinant $\mathrm{HCV}$ antigens (Core, NS3, NS4, NS5) are immobilized on a single test line on a nitrocellulose membrane. HBsAg or
anti-HCV antibodies in the samples reactive with these antibodies or antigens respectively are visualized by colloidal goldlabeled protein.

We purchased, or manufacturers donated POCTs for this validation study. The four manufacturers are All Test Biotech Hangzhou China, Hangzhou Voyage Medical Nantong China, Encode Medical Zhuhai China and Labratorium Hepatica Mataram, Indonesia. After initial evaluation on 20 to 50 patients, it had become evident that POCTs from only one manufacturer (All Test Biotech) was likely to meet our minimum test sensitivity requirement of $90 \%$. We continued the evaluation only for POCTs from this manufacturer.

Either finger-stick capillary or venepuncture wholeblood samples were collected from all subjects enrolled. The POCT procedures were performed according to the manufacturers' instructions. The reading times was 20 minutes, and tests should not be interpreted after 20 minutes. A POCT was interpreted as negative if a control line was present (regardless of intensity) with no corresponding test line. The appearance of a control line and a test line indicated a positive result. An unclear or missing control line indicated an invalid result, regardless of test line presence. In the event of the invalid result, the POCT was repeated until a valid result was obtained.Medical staff from each participating site performed the POCT. All medical staff had received prior training on the test procedure and interpretation. Only a single staff performed the test and read the result. Interoperator variability in test performance or interpretation of test results was not considered in this evalua tion.

\section{Statistical Methods}

We assessed the sensitivity and specificity of POCT for the detection of HBsAg and anti-HCV in a finger-stick capillary or venepuncture whole-blood samplescompared with test result from lab-based EIA or CLIA assay as the reference standard. Given the prevalence of chronic HBV or HCV among enrolled subjects is $50 \%$, for sensitivity and specificity of $99 \%$, and margin of error of $2.0 \%$, a minimum sample size of 190 would provide a $95 \%$ confidence intervals (CI) of 95 to $100.0 \%$ for the estimates of sensitivity and 95 to $100 \cdot 0 \%$ for specificity.

We estimate the $95 \%$ CIs for the sensitivity and specificity based on normal or Poisson approximations to the binomial distribution, as appropriate. ${ }^{29}$ Continuous variables were expressed as means with $\mathrm{SD}$ or medians with interquartile ranges (IQR).

\section{Lab Validation of HCV RNA and HBV DNA tests}

We also conducted a cross-sectional study to evaluate the diagnostic performance of a low cost in-house NAT 
for the detection of HCV RNA and HBV DNA between June and December 2017. The Ministry of Health's (MOH) Medical and Research Ethics Committee approved the study.

\section{Study Samples}

The study is conducted on serum specimen panel which was originally collected from patients with chronic HBV or HCV who had undergone testing for HCV RNA and HBV DNA as part of their routine medical care. We opportunistically use their leftover specimens for this validation study. The HBV DNA panel has 30 serum specimens from 2 laboratories in Malaysia, while the $\mathrm{HCV}$ RNA panel has 139 serum specimensfrom laboratories in Malaysia (30 samples), India (99 samples) and Myanmar (10 samples). The serum specimen was frozen at $-70^{\circ} \mathrm{C}$ until they were thawed for this study.

\section{NAT Tests under Evaluation and Procedures}

Hepatitis $C$ virus ribonucleic acid and HBV DNA were measured in stored serum samples usingin-house Applied Biosystem ${ }^{\circledR}$ TaqMan real-time PCR assay (ABS), the lower limit of detection (LOD) for HCV RNA and HBV DNA are $25 \mathrm{IU} / \mathrm{mL}$ and $10 \mathrm{IU} / \mathrm{mL}$ respectively. We compare these results with Roche Cobas ${ }^{\circledR}$ Ampliprep/ TaqMan assay (COBAS) for HCV RNA and HBV DNA

Table 1: Characteristics of patients enrolled in the validation study of anti-HCV and HBsAg POCT for use in public screening

\begin{tabular}{|c|c|c|c|}
\hline & $\begin{array}{l}\text { Patients } \\
\text { positive for } \\
\text { HBsAg }\end{array}$ & $\begin{array}{l}\text { Patients } \\
\text { positive for } \\
\text { anti-HCV }\end{array}$ & $\begin{array}{l}\text { Persons } \\
\text { negative } \\
\text { for HBsAg } \\
\text { and anti- } \\
\mathrm{HCV}\end{array}$ \\
\hline & $\mathrm{N}=145$ & $\mathrm{~N}=157$ & $\mathrm{~N}=150$ \\
\hline $\begin{array}{l}\text { Mean Age (SD), year } \\
\text { Gender }\end{array}$ & $50(13)$ & $52(12)$ & $52(12)$ \\
\hline Male, $\%$ & $68 \%$ & $66 \%$ & $40 \%$ \\
\hline Female, \% & $32 \%$ & $34 \%$ & $60 \%$ \\
\hline \multicolumn{4}{|l|}{ Ethnicity } \\
\hline Malay, \% & $44 \%$ & $57 \%$ & $10 \%$ \\
\hline Chinese, \% & $49 \%$ & $32 \%$ & $83 \%$ \\
\hline Indian, \% & $2 \%$ & $11 \%$ & $6 \%$ \\
\hline Others, \% & $4 \%$ & $0 \%$ & $3 \%$ \\
\hline \multicolumn{4}{|l|}{ Sites } \\
\hline $\begin{array}{l}\text { Medical/Gastroenterology } \\
\text { clinic, \% }\end{array}$ & $74 \%$ & $43 \%$ & - \\
\hline $\begin{array}{l}\text { Hemodialysis centres, \% } \\
\text { Individual sites }\end{array}$ & $26 \%$ & $57 \%$ & - \\
\hline Hospital RPB Ipoh & $38 \%$ & $22 \%$ & - \\
\hline Hospital SHAS Temerloh & $24 \%$ & $20 \%$ & - \\
\hline Hospital TAA Kuantan & $23 \%$ & $22 \%$ & - \\
\hline Hospital Kuala Lumpur & $11 \%$ & $24 \%$ & - \\
\hline $\begin{array}{l}\text { Hospital Sungai Buloh \& } \\
\text { Others }\end{array}$ & $4 \%$ & $3 \%$ & - \\
\hline Others & $0 \%$ & $8 \%$ & - \\
\hline
\end{tabular}

as the reference standard (LOD for HCV RNA and HBV DNA are $15 \mathrm{IU} / \mathrm{mL}$ and $20 \mathrm{IU} / \mathrm{mL}$ respectively).

\section{Statistical Methods}

We used Bland-Altman difference plot $^{30}$ to assess the limits of agreement(LOA) in the quantification of serum HBV DNA and HCV RNA between the in-house ABS assay compared with COBAS assay as the reference.

Assuming the mean difference between the two assays is zero, and SD $0.25 \log 10 \mathrm{IU} / \mathrm{mL}$, a minimum sample size of 30 specimens would provide a $95 \% \mathrm{CI}$ of $+0.15 \log 10 \mathrm{IU} / \mathrm{mL}$. All results are reported in $\log 10$ units. Data for specimens having results below the lower limit of detection (LOD) were imputed using the midpoint between zero and LOD.

\section{RESULTS}

Table 1 shows the characteristics of the subjects enrolled in the validation study of anti-HCV and HBsAg POCT for use in public screening. Their mean age was 51 years. $67 \%$ of the patients were male. Most patients (74\%) positive for HBsAg were enrolled from Medical and Gastroenterology clinics, while patients positive for anti-HCV were mostly (57\%) enrolled from Hemodialysis centers.

Tables 2 and 3 show the diagnostic performance of the POCT for HBsAg and anti-HCV respectively. The POCT for detecting HBsAg has a sensitivity of $95.2 \%$ and specificity $100 \%$, giving an overall accuracy of $97.6 \%$. The POCT for detecting anti-HCVhas a sensitivity of $98.1 \%$ and specificity $100 \%$, giving an overall accuracy of $99.0 \%$. These results provide adequate evidence of the diagnostic validity of POCT for anti-HCV and HBsAg for use in public screening.

Figure 1 shows the Bland-Altman plot. HBV DNA concentrations detected by the ABS assay were a mean of

Table 2: Diagnostic performance of POCT for detecting HBsAg validated against positive HBsAg by EIA or CLIA as the diagnostic standard

\begin{tabular}{lll}
\hline & $\begin{array}{l}\text { Positive } \\
\text { HBsAg by }\end{array}$ & $\begin{array}{l}\text { Negative } \\
\text { HBsAg by } \\
\text { EIA }\end{array}$ \\
& EIA & $0(0 \%)$ \\
\hline Positive HBsAg by POCT & $138(95.2 \%)$ & $0(150(100 \%)$ \\
Negative HBsAg by POCT & $7(4.8 \%)$ & $150(100 \%)$ \\
Total & $145(100 \%)$ & 150 \\
\hline
\end{tabular}

Table 3: Diagnostic performance of POCT for detecting anti$\mathrm{HCV}$ validated against positive Anti-HCV by EIA or CLIA as the diagnostic standard

\begin{tabular}{lll}
\hline & $\begin{array}{l}\text { Positive anti- } \\
\text { HCV by EIA or } \\
\text { CLIA }\end{array}$ & $\begin{array}{l}\text { Negative anti- } \\
\text { HCV by EIA or } \\
\text { CLIA }\end{array}$ \\
\hline $\begin{array}{l}\text { Positive Anti-HCV by } \\
\text { POCT }\end{array}$ & $154(98.1 \%)$ & $0(0 \%)$ \\
$\begin{array}{l}\text { Negative Anti-HCV by } \\
\text { POCT }\end{array}$ & $3(1.9 \%)$ & $150(100 \%)$ \\
Total & $157(100 \%)$ & $150(100 \%)$ \\
\hline
\end{tabular}



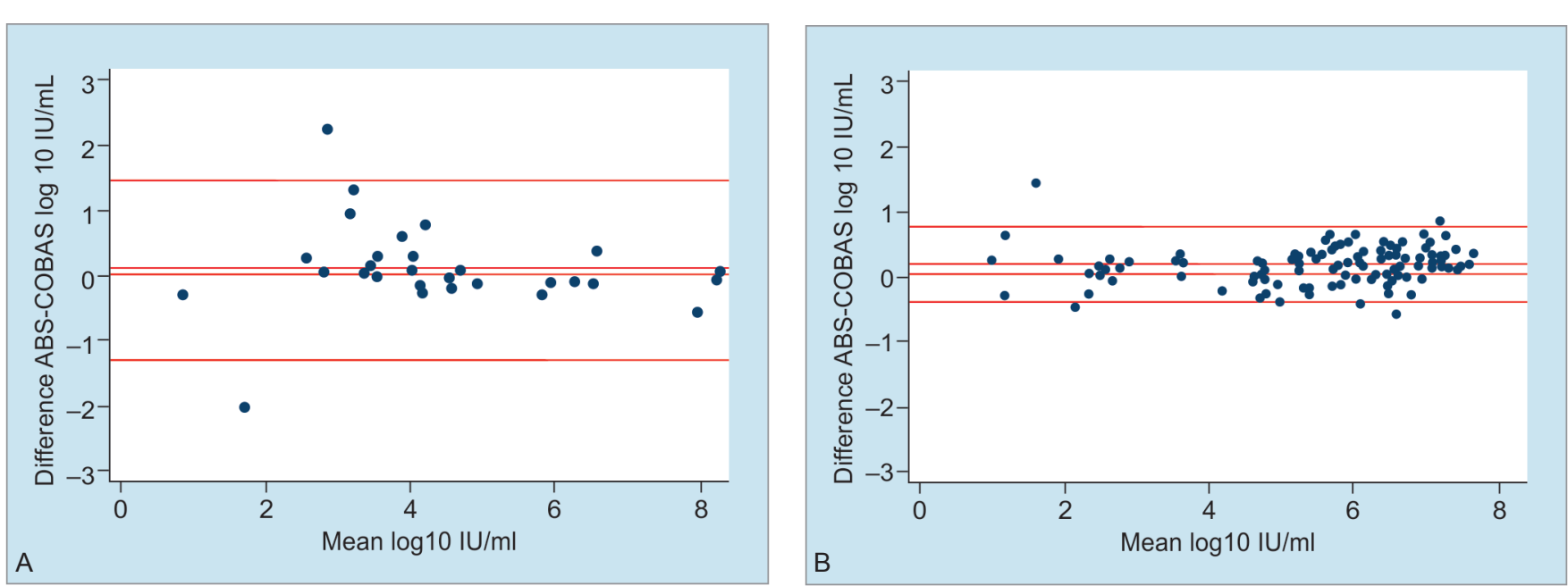

Figs 1A and B: Bland-Altman bias plot of differences. (A) Applied Biosystem TaqMan assay for HBV DNA in serum samples compared with Roche Cobas Ampliprep/TaqMan assay. $N=30$, bias $0.10,95 \%$ limits of agreement -1.28 to 1.47 ; (B) Applied Biosystem TaqMan assay for HCV RNA in serum samples compared with Roche Cobas Ampliprep/TaqMan assay. $\mathrm{N}=139$, bias $0.17,95 \%$ limits of agreement -0.41 to 0.75

0.10 (SD 0.69) $\log 10 \mathrm{IU} / \mathrm{mL}$ higher than those measured by the COBAS assay. The limits of agreement indicate that $95 \%$ of the differences between the two assays are between -1.23 and $1.47 \log 10 \mathrm{IU} / \mathrm{mL}$.

HCV RNA concentrations detected by the ABS assay were a mean of 0.17 (SD 0.29) $\log 10 \mathrm{IU} / \mathrm{mL}$ higher than those measured by the COBAS assay. The limits of agreement indicate that $95 \%$ of the differences between the two assays are between -0.41 and $0.75 \log 10 \mathrm{IU} / \mathrm{mL}$.

\section{DISCUSSION}

We conducted a diagnostic performance study on four low-cost POC Ts for detecting HBsAg and anti-HCV in whole-blood collected by finger-stick or venepuncture compared with EIA or CLIA assay as the reference standard. Consistent with results from previous studies, ${ }^{31}$ we found a wide range of sensitivity, and evaluation on three of the four selected POCTs were abandoned early on account of suboptimal sensitivity.

Fortunately, we identify one POCT with sensitivity and specificity of $95.2 \%$ and $100 \%$ for detecting HBsAg. These results are consistent if not better than results from 30 studies on 33 POCTs conducted in 23 countries with varying prevalence. The pooled estimate of the sensitivity was $90.0 \%$ (95\% CI: 89.1-90.8) and pooled specificity $99.5 \%$ (95\% CI: 99.4-99.5). ${ }^{31}$ Our sensitivity result seems higher than those reported in published studies to date, which may be because we excluded subjects with a history of $\mathrm{HBV}$ vaccination. Of the seven subjects in this study who had a false negative result on the POCT for HBsAg, one had anti-HBs, one had anti-HBe, five had low HBV DNA $(<10,000 \mathrm{IU} / \mathrm{mL})$, two had seroconverted to HBeAg-.

We also identify one POCT with sensitivity and specificity of $98.1 \%$ and $100 \%$ respectively for detecting
anti-HCV. This is also consistent with previous studies which have found that POCT for anti-HCV performed much better than for HBsAg. A systematic review of 32 studies on 25 POCT brands reported a pooled sensitivityand specificity of $99 \%$ (95\% CI $98-100 \%)$ and $100 \%$ (95\% CI100-100\%) respectively. ${ }^{32}$

We also conducted a diagnostic performance study on a low-cost in-house Applied Biosystem ${ }^{\circledR}$ TaqMan assayfor the detection of HCV RNA and HBV DNA in stored serum panel compared with Roche Cobas ${ }^{\circledR}$ Ampliprep/ TaqMan assay as the reference. For the quantification of both HBV DNA and HCV RNA, results from our in-house assay were systematically higher (positive bias of 0.10 and $0.17 \log 10 \mathrm{IU} / \mathrm{mL}$ respectively) than those from the COBAS assay. The range of their $95 \%$ limits of agreement 2.75 and $1.16 \log 10 \mathrm{IU} / \mathrm{mL}$ respectively, however, are comparable to previous studies comparing two NAT methods. ${ }^{33,34}$ The limits of agreement indicate that $95 \%$ of the differences between Applied Biosystem ${ }^{\circledR}$ TaqMan assay and the Roche Cobas ${ }^{\circledR}$ Ampliprep/TaqMan assay is between -1.28 and $1.47 \log 10 \mathrm{IU} / \mathrm{mL}$ (0.05 to $29.5 \mathrm{IU} /$ $\mathrm{mL}$ ) for HBV DNA, and between- 0.41 and $0.75 \log 10 \mathrm{IU} /$ $\mathrm{mL}$ (0.39 to $5.6 \mathrm{IU} / \mathrm{mL})$ for HCV RNA. These differences are not clinically significant.

One limitation of this study is that the participants in this study were enrolled from medical clinics or dialysis centers. They may not be representative of the target population in our public screening campaign. Our results may not be generalizable to the broader population setting, and ongoing monitoring of the tests' performance during the public screening campaign is warranted.

In conclusion, our results on the POCTs evaluated in this study provide support for broader use in our Hepa- 
titis public screening campaign. Similarly, the results on the diagnostic performance of the NATs give us the confidence to adopt these low-cost NATs for broader use to support our Hepatitis treatment campaign.

\section{DECLARATIONS}

\section{Ethics Approval and Consent}

The Ministry of Health's (MOH) Medical and Research Ethics Committee approved the study. All patients enrolled for the validation study of POCT for detecting anti-HCV and HBsAg gave written informed consent

\section{AUTHOR'S CONTRIBUTIONS}

MRAH, TSS, RM, FJ, SK, ACA, GAK, WHS, RA, MRS, MAM, ZM contributed to the subject matter expertise. They also contributed to the writing of the manuscript. LTO conceived the idea behind this study and contributed to the study design, data analysis and interpretation, report writing and subject matter expertise. All authors read and approved the final manuscript.

\section{ACKNOWLEDGMENTS}

Authors would like to extend their sincere gratitude and appreciation to the following investigators and coinvestigators Lim EK, Lee FY, Kiren K, Lim BC, Fatihah Mahmud, Chang CT, Izzaty D, Korina K, Murnilina AM, Nurul A, Selva Kumar, Suryati Y, Lee YY, Loh CL, Sridhar R, Alif Adlan Mohd Thabit, Wan Mohd Rasis, Fariz Safhan, Salbiah Nawi and Harvinder Kaur Laknbeer Singh. Including Ms Teo Jau Shya, Huziana Fauzi and Ms Lena Yeap for their efforts in managing and analyzing the data. Authors thank All Test Biotech Hangzhou China for providing the POCT kits in our screening campaign. They wish to thank all those whose names are not mentioned here who render their excellent service, especially during the data collection.

\section{REFERENCES}

1. Institute for Health Metrics and Evaluation., (n.d.). Global Burden Of Diseases, Injuries, And Risk Factors Study 2010, Gbd Profile: Malaysia. Available from http://www.healthdata.org/sites/default/files/files/country_profiles/ GBD/ ihme_gbd_country_report_malaysia.pdf

2. Mokdad AA, Lopez AD, Shahraz S, Lozano R, Mokdad AH, Stanaway J, et al. Liver cirrhosis mortality in 187 countries between1980 and 2010: a systematic analysis. BMC Medicine 2014,12:145

3. Ferlay J, Soerjomataram I, Ervik, M, Dikshit R, Eser S, Mathers, C. (n.d.). GLOBOCAN 2012: Estimated cancer incidence, mortality and prevalence worldwide in 2012 v1.0. IARC CancerBase 2014,11.

4. Duraisamy G, Zuridah H, Ariffin MY.Prevalence of hepatitis $C$ virus antibodies in blood donors in Malaysia. Med J Malaysia. 1993 Sep;48(3):313-316.
5. Ng KP, Saw TL, Wong NWD, Chuah SY et al. The prevalence of Anti-HCV antibody in risk groups and blood donors. Med J Malaysia 1995;50:302-305

6. Sinniah M, Ooi BG. Hepatitis C-the Malaysian story. Singapore Med J. 1993 Apr;34(2):132-134.

7. Lee WS, Ng KP. Seroprevalence of Anti-HCV in an Urban Child Population: A Preliminary Study from Kuala Lumpur. Singapore Med J 2001;42(3):100-101.

8. Malaysia National Renal Registry. Annual Reports of the Malaysian Dialysis and Transplant Registry 2012. Available at: https://www.msn.org.my/nrr/mdtr2012.jsp

9. McDonald SA, Mohamed R, Dahlui M, Naning H, Kamarulzaman A. Bridging the data gaps in the epidemiology of hepatitis $C$ virus infection in Malaysia using multi-parameter evidence synthesis. BMC Infect Dis. 2014 Nov 7;14:564.

10. McDonald SA, Dahlui M, Mohamed R, Naning H, Shabaruddin FH, Kamarulzaman A. Projections of the Current and Future Disease Burden of Hepatitis C Virus Infection in Malaysia. PLoS ONE June 2015;10(6):e0128091.

11. Lopez CG. Epidemiology of persistent hepatitis B virus infection. Malaysian J Pathol 1985 Aug;7:7-10.

12. Tan TC, Vadivale M, Ong CN. Prevalence of Hepatitis B Surface Antigen and Antibody among Health Care Employees in Negri Sembilan, Malaysia, 1989. Asia Pac J Public Health 1992-1993;6:134-139.

13. Ng KP, Ngeow YF, Rozainah K, Rosmawati M. Hepatitis B seroprevalence among University of Malaya Students in the Post-universal Infant Vaccination Era. Med J Malaysia 2013; Apr;68(2):144-147.

14. Ng KP, Saw TL, Baki A, Rozainah K, Pang KW, Ramanathan M. Impact of Expanded Programme of Immunization on hepatitis B infection in school children in Malaysia. Med Microbiol Immunol 2005 May;194(3):163-168.

15. Cheang HK, Wong HT, Ho SC, Chew KS, et al. Immune response in infants after universal hepatitis $\mathrm{B}$ vaccination, a community based study in Malaysia. Sing Med J 2013;54:224226

16. Yap SF. Chronic hepatitis B infection in Malaysians. Malays J Pathol. 1994 Jun;16:3-6.

17. Raihan R. Hepatitis in Malaysia, past present \& future, EuroAsian J Hepato-Gastroenterol 2016;Jan-Jun;6(1): 52-55.

18. Hanafiah KM, Groeger J, Flaxman AD, Wiersma ST. Global Epidemiology of Hepatitis C Virus Infection: New Estimates of Age-Specific Antibody to HCV Seroprevalence. Hepatology 2013 Apr; 57(4):1333-1342

19. Schweitzer A, Horn J, Mikolajczyk R, Krause G, Ott JJ. Estimations of worldwide prevalence of chronic hepatitis $\mathrm{B}$ virus infection: a systematic review of data published between 1965 and 2013. Lancet 2015; Oct 17;386(10003):1546-55.

20. Ott JJ, Stevens GA, Groeger J, Wiersma ST. Global epidemiology of hepatitis B infection: new estimates of age-specific HBsAg seroprevalence and endemicity. Vaccine 2012 Mar 9;30(12):2212-2219.

21. Wedemeyer $\mathrm{H}$. Towards interferon-free treatment for all HCV genotypes. Lancet 2015 Jun 20;385(9986):2443-245.

22. Kaur RP, Ho GF, Mastura MY, Goh PP, Salowi MA, Radzi M, et al. The elephant in the room-Universal coverage for Costly treatments in an upper middle income country. bioRxiv. 2017:21(4)29-36. 
23. Hepatitis Free Pahang Malaysia. Available from https://hepatitisfreemsia.org.my/

24. Philippa J. Easterbrook, on behalf of the WHO Guidelines Development Group. Who to test and how to test for chronic hepatitis C infection -2016 WHO testing guidance for lowand middle-income countries. Journal of Hepatology 2016; Oct;65:S46-S66

25. Freeman J, Sallie R, Kennedy A, Hieu PT, Jeffreys G, Hill AM. High sustained virological response rates using generic direct acting antiviral treatment for hepatitis C, imported into Australia. Journal of Hepatology. 2016 Jan 1;64(2): S209.

26. Ghinea N, Lipworth W, Day R, Hill A, Dore GJ, Danta M. Importation of generic hepatitis $C$ therapies: bridging the gap between price and access in high-income countries. Lancet 2017 March 25;389:1268-1272

27. WHO. Guidelines for the prevention, care and treatment of persons with hepatitis B infection. Geneva: WHO; March 2015 http://www.who.int/hepatitis/publications/hepatitis-b-guidelines/ en/

28. WHO. Guidelines for the screening, care and treatment of persons with chronic hepatitis $\mathrm{C}$ infection. Updated version, April 2016. Geneva: World Health Organization; 2016 http:// apps.who.int/iris/bitstream/10665/205035/1/9789241549615_eng. pdf?ua $=1$

29. Fleiss J. Statistical Methods for Rates and Proportions. 2nd ed. New York, NY: John Wiley \& Sons Inc; 1981

30. Bland JM, Altman DG. Statistical methods for assessing agreement between two methods of clinical measurement. Lancet 1986 Feb 8;327(8476):307-310.

31. WHO guidelines on hepatitis B and C testing. Geneva: World Health Organization; Feb 2017. License: CC BY-NC-SA 3.0 IGO.

32. Easterbrook PJ. On behalf of the WHO Guidelines Development Groupl. Who to test and how to test for chronic hepatitis Cinfection 2016 WHO testing guidance for low- and middleincome countries. Journal of Hepatology 2016 Oct; 65:S46S66

33. McHugh MP, Wu AHB, Chevaliez S, Pawlotsky JM, Hallin M, Templeton KE. Multicentre Evaluation of the Cepheid Xpert ${ }^{\circledR}$ Hepatitis C Virus (HCV) Viral Load Assay. J Clinical Microbiol 2017 May;55(5):1550-1556.

34. rebely J, Lamoury FMJ, Hajarizadeh B, Mowat Y, Marshall AD, Bajis S, et al. Evaluation of the Xpert HCV Viral Load point-of-care assay from venepuncture-collected and fingerstick capillary whole-blood samples: a cohort study. Lancet Gastroenterol Hepatol 2017, Jul;2(7):514-520. 